\title{
DR. 1017
}

ANL/PAG-2

\section{MASTER}

\section{Biological Removal of Organic Constituents}

in Quench Waters from High-Btu

Coal-Gasification Pilot Plants

V. C. Stamoudis and R. G. Luthy 


\section{DISCLAIMER}

This report was prepared as an account of work sponsored by an agency of the United States Government. Neither the United States Government nor any agency Thereof, nor any of their employees, makes any warranty, express or implied, or assumes any legal liability or responsibility for the accuracy, completeness, or usefulness of any information, apparatus, product, or process disclosed, or represents that its use would not infringe privately owned rights. Reference herein to any specific commercial product, process, or service by trade name, trademark, manufacturer, or otherwise does not necessarily constitute or imply its endorsement, recommendation, or favoring by the United States Government or any agency thereof. The views and opinions of authors expressed herein do not necessarily state or reflect those of the United States Government or any agency thereof. 


\section{DISCLAIMER}

Portions of this document may be illegible in electronic image products. Images are produced from the best available original document. 
The facilities of Argonne National Laboratory are owned by the United States Government. Under the terms of a contract (W-31-109-Eng-38) among the U. S. Department of Energy, Argonne Universities Association and The University of Chicago, the University employs the staff and operates the Laboratory in accordance with policies and programs formulated, approved and reviewed by the Association.

\section{MEMBERS OF ARGONNE UNIVERSITIES ASSOCIATION}

The University of Arizona

Carnegie-Mellon University

Case Western Reserve University

The University of Chicago

University of Cincinnati

Illinois Institute of Technology

University of Illinois

Indiana University

The University of Iowa

Iowa State University
The University of Kansas

Kansas State University

Loyola University of Chicago

Marquette University

The University of Michigan

Michigan State University

University of Minnesota

University of Missouri

Northwestern University

University of Notre Dame
The Ohio State University

Ohio University

The Pennsylvania State University

Purdue University

Saint Louis University

Southern Illinois University

The University of Texas at Austin

Washington University

Wayne State University

The University of Wisconsin-Madison

\section{NOTICE}

This report was prepared as an account of work sponsored by an agency of the United States Government. Neither the United States Government or any agency thereof, nor any of their employees, make any warranty, express or implied, or assume any legal liability or responsibility for the accuracy, completeness, or usefulness of any information, apparatus, product, or process disclosed, or represent that its use would not infringe privately owned rights. Reference herein to any specific commercial product, process, or service by trade name, mark, manufacturer, or otherwise, does not necessarily constitute or imply its endorsement, recommendation, or favoring by the United States Government or any agency thereof. The views and opinions of authors expressed herein do not necessarily state or reflect those of the United States Government or any agency thereof.

Printed in the United States of America

Available from

National Technical Information Service

U. S. Department of Commerce

5285 Port Royal Road

Springfield, VA 22161

NTIS price codes

Printed copy: A03

Microfiche copy: A01 
Distribution Category:

Coal Conversion and Utilization-Coal Gasification (UC-90c)

ANL/ PAG - 2

\begin{abstract}
ARCONNE NATIONAL LABORATORY
9700 South Cass. Avenue

Argonne, Illinois 60439
\end{abstract}

BIOLOGICAL REMOVAL OF ORGANIC CONSTITUENTS

IN QUENCH WATERS FROM HIGH-BTU

COAL-GASIFICATION PILOT PLANTS

by

Vassilis C. Stamoudis and Richard G. Luthy*

Energy and Environmental Systems Division Pollutant Analysis and Geochemistry Section

February 1980

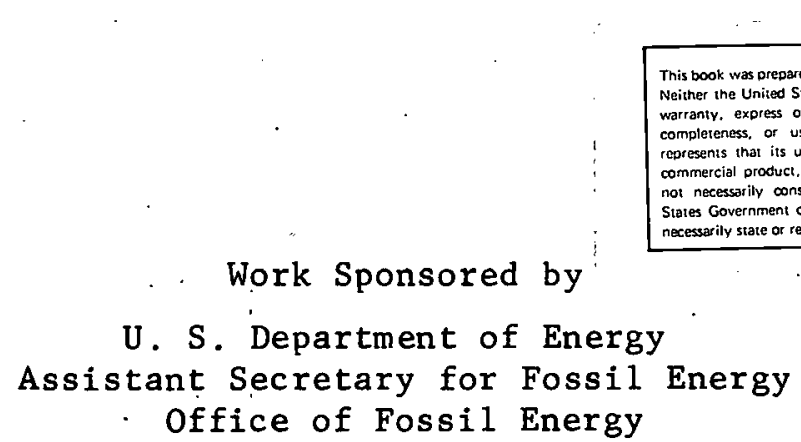

Office of Fossil Energy

*Department of Civil Engineering, Carnegie-Mellon University 
CONTENTS

Page

ABSTRACT. . . . . . . . . . . . . . . . . . . . . . 1

1 INTRODUCTION . . . . . . . . . . . . . ....... 1

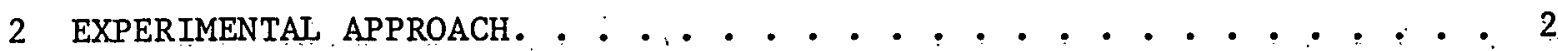

2.1 Sample Representativeness . . . . . . . . . . . . . . 2

2.2 Quench Water Collection anḍ Storage.. . . . . . . . . . . 2

2.3 Quench Water Pretreatment ... . . . . . . . . . . . . 3

2.4 Biological oxidation. . . . ................ 3

2.5 Analytiçal Techniques . . . . . . . . . . . . . . 5

3 EXPERIMENTAL RESULLTS . . . . . . . . . . . . . . . . . 7

3.1 Biological Reactor Characteristics. ............. 7

3.2 Removal Efficiency of Organic Compounds . . . ........ 8

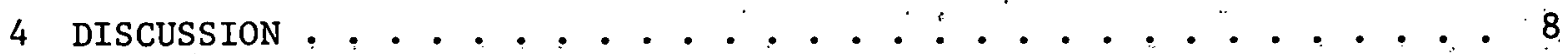

4.1 Acid Fractions. . . . . . . . . . . . . . . 8

4.2 Base Fractions. . . . . . . . . . . . . . . . . . . 15

4.3 Neutral Fractions ................... 19

5 CONCLUSIONS. . . . . . . . . . . . . . . . . . . 20

6 RECOMMENDATIONS. . . . . . . . . . . . . . . . . . 20

ACKNOWLEDGMENTS . . . . . . . . . . . . . . . . . . . 21

REFERENCES. . . . . . . . . . . . . . . . . . . . 21 
LIST OF FIGURES

No.

Title

Page

1. Extraction Scheme for Biological Reactor Influent and

Effluent Samples. . . . . . . . . . ......... 6

2 Plot of Total-Ion and Single-Ion Areas vs

Concentration for Benzonitrile :. . . . . . . . . . . . 6

3 Total-Ion Chromatograms of Influent and Effluent Acid-

Fraction Extracts of Biologically Treated HYGAS

and SFB Quench Waters................... . 10

4 Total-Ion Chromatograms of Influent and Effluent Base-

Fraction Extracts of Biologically Treated HYGAS

and SFB Quench Waters ..................... . 11

5. Total-Ion Chromatograms of Influent and Effluent Neutral-

Fraction Extracts of Biologically Treated HYGAS and

SFB Quench Waters ..... . . . . . . . . . . . . 12

\section{LIST OF TABLES}

1 Representative Raw Quench Water. Characteristics

during Biological oxidation Studies . . . . . . . . . . . . 4

2 Percent Recoveries of Organics Extracted from Spiked

Distilled Water Based on GC Analysis. . . . . . . . . . . 7

3. Average Biological Reactor Performance Data for Evaluation

of Removal of Trace Organic Compounds . . . . . . . . . . . . 9

4 Concentration of Acid-Fraction Organic Constituents in Influent and Effluent Quench Waters by Activated-Sludge at Bench Scale, Together with the Percent Removal Values. . . . . . . . . . 13

5 Concentration of Base-Fraction Organic Constituents in Influent and Effluent Quench Waters by Activated-Sludge at Bench Scale, Together with the Percent Removal Values. . . . . . . . . . 14

6 Concentration of Neutral-Fraction Organic Constituents in Influent and Effluent Quench Waters by Activated-Sludge at Bench Scale, Together with the Percent Removal Values . . . . . 16 


\section{BIOLOGICAL REMOVAL OF ORGANIC CONSTITUENTS IN QUENCH WATERS FROM HIGH-BTU COAL-GASIFICATION PILOT PLANTS}

by

Vassilis C. Stamoudis and Richard G. Luthy

\section{ABSTRACT}

Studies were initiated to assess the efficiency of bench-scale, activated-sludge treatment for removal of organic constituents from coal-gasification process effluents. Samples of pilot-plant, raw-gas quench waters were obtained from the HYGAS process of the Institute of Gas Technology and from the slagging, fixed-bed (SFB) process of the Grand Forks Energy Technology Center. The types of coal employed were Bituminous Iliinois No. 6 for the HYGAS and Indian Head lignite for the SFB process. These pilot-plant quench waters, while not strictly representative of commercial condensates, were considered useful to evaluate the efficiency of biological oxidation for the removal of organics.

Biological-reactor influent and effluent samples were extracted using a methylene chloride $\mathrm{pH}$-fractionation method into acid, base, and neutral fractions, which were analyzed by capillary-column gas-chromatography/mass-spectrometry. Influent acid fractions of both HYGAS and SFB condensates showed that nearly $99 \%$ of extractable and chromatographable organic material comprised phenol and alkylated phenols. Activated-sludge treatment removed these compounds almost completely. Removal efficiency of base-fraction organics was generally good, except for certain alkylated pyridines. Removal of neutral-fraction organics was also good, except for certain alkylated benzenes, certain polycyclic aromatic hydrocarbons, and certain cycloalkanes and cycloalkenes, especially at low influent concentrations.

\section{INTRODUCTION}

Diminishing supplies of petroleum and natural gas have stimulated interest in processes that convert coal into synthetic liquid and gaseous products. High-Btu coal gasification entails the reaction of coal, steam, and oxygen at elevated temperature and pressure to produce a raw gas that can be upgraded to yield a methane-rich product. A number of pilot-plant coa1gasification tests are in progress to evaluate improved process efficiencies and to perform environmental assessment studies in conjunction with process development research. The purpose of this investigation is to characterize and to assess removal efficlencies for organic constituents from the biologically treated raw-gas quench condensates of two high-Btu coalgasification pilot plants. This investigation will aid environmental assessment of coal conversion. processes, as a review of the available 
literature (Singer et al., 1978; Stamoudis, Luthy, and Harrison, 1979; White and Schmidt, 1978) has shown that very limited studies have been performed with actual pilot-plant or process condensates to address issues relevant to removal of trace organic constituents.

\section{EXPERTMENTAL APPROACH}

The quench waters selected for study were obtained from the HYGAS. steam-oxygen pilot plant, operated by the Institute of Gas Technology of Chicago; Illinois, and from the slagging, fixed-bed (SFB) pilot plant operated by the Grand Forks Energy Technology Center (GFETC) of North Dakota. Descriptions of the pilot-plant effluent flow distributions and pilot-plant test program are provided by Jonardi et al. (19.79) and Ellman et al. (1979) for the pilot-plant runs from which quench waters were obtained for the HYGAS and SFB processes, respectively. Quench waters from these processes were selected for study because: (1) they represent major DOE-sponsored coal gasification systems in an advanced. state of development, (2) they are contaminated with organic pollutants, and (3) they have the biologically treatable characteristics that have been the subject of recent experimental investigations (Luthy and Talion, 1978; Luthy.et a1., 1979)

\subsection{SAMPLE REPRESENTATIVENESS}

It is important to recognize that the pilot-plant quench waters used in this study are not representative in a quantitative sense of wastewaters that would be expected in a demonstration or commercial scale HYGAS or SFB coalgasification plant. This is due to.a number of critical factors that differ between pilot and conceptual larger scale facilities. These factors include gasifier operating conditions, raw gas-quenching design and efficiency, and differences in flow rates and combinations of various aqueous waste and process streams. The pilot-plant quench water samples used, however, are qualitatively representative of the types of trace organic contaminants that could be present in larger scale coal-gasification plant wastewaters. Given this perspective, it should be clear that the quench water concentrations reported here (biological-reactor influents and effluents) are not necessarily directly related to expected larger scale plant wastewaters and that comparisons of HYGAS and SFB quench water samples are only meaningful in the context of bench-scale biological reactor performance.

\subsection{QUENCH WATER COLLECTION AND STORAGE}

Details regarding procedures employed in quench water collection and transport are documented in reports by Stamoudis, Luthy, and Harrison (1979) and Stamoudis and Luthy (1979). Raw quench water was collected during HYGAS pilot-plant runs 62 and 64 and represented gasification of Illinois No. 6 bituminous coal. Quench water was collected in approximately 300- to 350-gal quantities from each run with effluent from run 64 being used primarily during the steady-state period of biological reactor testing. The slagging fixed-bed effluent was generated during gasifier run RA-52 with Indian Head lignite. Approximately 250 gal of decanted quench water was shipped to Carnegie-Mellon 
University via freezer truck. It was necessary to provide means for storage of quench water samples because of the long-term duration of the biological treatability studies. In these investigations quench water storage was achieved by freezing until needed as feed for the biological reactors:

Raw quench water samples collected at the pilot-plant facilities were stored and shipped in plastic containers because of the large quantities of quench water being handled. Biological reactor effluent from the HYGAS study, also stored in a plastic container, was frozen because the biological oxidation experiment 'preceded by several months the trace-organics characterization studies. Biological reactor effluent from the SFB study was collected fresh and not stored in plastic containers. Although no studies were performed to assess the stability of trace organics in frozen samples, a recent Argonne National Laboratory (ANL) investigation of the stability of HYGAS quench water suggests that a high degree of stability for the extractable/chromatographable components could be expected (Raphaelian and Harrison, 1979).

\subsection{QUENCH WATER PRETREATMENT}

Representative raw quench water characteristics for the samples used in this investigation are given in Table 1. Raw quench water was pretreated to reduce excess alkalinity and ammonia concentrations by lime addition and air stripping. This pretreatment simulated the free and fixed-leg ammonia removal that would be expected in a commerical treatment train. It was found that ammonia-stripped HYGAS quench water could be processed through a biological reactor at full strength without dilution. However, a series of sequential and parallel tests with stripped SFB effluent in which feed strength and lnading were varied independently showed that this wastewater could not. be processed at full strength. Stable biological reactor performance was achieved by diluting to $33 \%$ strength with tap water. (Trace-organics characterization data reported later in Tables 4, 5, and 6 for treatment of SFB quench water were adjusted by a factor of three in order. to express results on an equivalent undiluted basis.)

\subsection{BIOLOGICAL OXIDATION}

The biological reactiors employed in this study were complete-mix, single-stage, air-activated sludge reactors with internal clarifiers. These reactors were operated under conditions whereby hydraulic residence time, mean bacterial-cell residence time, and feed strength were held as experimental constants. Dependent variables were steady-state values of mixed-1iquor volatile suspended solids (MLVSS) and effluent substrate concentration. The biological reactors were acclimatized to the quench waters over a sufficiently long period of time that the reactors were subjected to three complete bacterial sludge wasting cycles prior to the collection of steady-state performance data. Reactors were then operated for 7-8 weeks during which a 23-week composite sample was collected for trace-organics analysis. 
Table 1. Representative Raw Quench Water Characteristics during Biological Oxidation Studies $^{a}$

\begin{tabular}{|c|c|c|}
\hline Parameter $b$ & $\begin{array}{l}\text { HYGAS } c, d \\
\text { (Run 64) }\end{array}$ & $\begin{array}{c}S F B d, e \\
\text { (Run RA-52) }\end{array}$ \\
\hline COD & 4,050 & 25,400 \\
\hline Phenolics & 710 & $-5,100$ \\
\hline $\mathrm{NH}_{3}-\mathrm{N}$ & 3,700 & 5,200 \\
\hline NO $_{3}$ & $<2$ & $<2$ \\
\hline Organic-N & 10 & 90 \\
\hline $\mathrm{CN}_{\text {tot }}^{-}: \quad \cdot$ & 0.3 & 12 \\
\hline $\mathrm{SCN}^{-}$ & 28 & 140 \\
\hline$s^{2-}$ & 140 & 150 \\
\hline $\mathrm{so}_{4}^{\prime 2-}$ & 180 & 150 \\
\hline $\mathbf{P}$ & 1 & 13 \\
\hline Alkalinity (as $\mathrm{CaCO}_{3}$ ) & 12,600 & 18,400 \\
\hline Total Acidity (as $\mathrm{CaCO}_{3}$ ) & -- & 24,000 \\
\hline Total Oil \& Grease & -- & 300 \\
\hline Soluble Oil \& Grease & - & 190 \\
\hline Conductivity $(\mu \mathrm{mhos} / \mathrm{cm})$ & 19,000 & 20,000 \\
\hline $\mathrm{pH}$ (units) & 7.8 & 8.4 \\
\hline
\end{tabular}

${ }^{a}$ Refer to section on sample representativeness for limitations on data interpretation.

${ }^{b}$ All units in $\mathrm{mg} / \mathrm{L}$ except as noted.

CQuench water comprised a 1:1 mixture of cyclone and quench condensates.

HYGAS data from Luthy and Tallon (1978); SFB data from Luthy, Sekel, and Tallon (1979).

e Double-decanted gasifier quench condensate. 


\subsection{ANALYTICAL TECHNIQUES}

Organic constituents were extracted by methylene chloride, using generally accepted techniques, into acid, base, and neutral fractions. The extraction scheme used in this investigation is shown in Fig. 1. Emulsion problems were minimized by manipulating the sample to enhance phase separation (Stamoudis et al., 1979; Stamoudis and Luthy, 1979).

Organics in acid, base, and neutral fractions were analyzed via gaschromatography/mass-spectrometry (GC/MS) using a Hewlett-Packard 5984A GC/MS equipped with a Hewlett-Packard 5934A Data System. A 5830 Hewlett-Packard GC was used in place of the 5700 -series Hewlett-Packard GC normally delivered with the. $5982 \mathrm{~A} \mathrm{GC} / \mathrm{MS}$. Glass capillary, wall-coated, open-tubular columns were used (Perkin-Elmer, 0.25-mm ID, 50-m-1ong, oV-101). The temperature was programmed from 20 to $240^{\circ} \mathrm{C}$ at $2^{\circ} / \mathrm{min}$, with a $2-\mathrm{min}$ hold at $20^{\circ} \mathrm{C}$. Compound identification was based on mass spectra and known retention times.

The percentage removal of individual compounds was estimated by obtaining the total-ion chromatograms of both influent and effluent and comparing the total-ion counts of the various peaks. The assumptions employed were:

a. Each compoünd found in the influent also could be present in the effluent (with the same chromatographability),

b. The concentration levels of the compounds are in the optimum range of linearity in a total-ion (or singleion) vs concentration plot, and

c. The extraction yields for individual compounds in the influent and effluent are the same.

The first assumption is a plausible one and a corollary to this is that, if a compound is not detectable in the effluent, it is $100 \%$ removed. In order to substantiate the second assumption it would be necessary to determine the total-ion (or single-ion) area as a. function of concentration for each compound or for a few compounds serving as models for the others. Figure 2 shows the results of such a study involving benzonitrile, which gave good linearity over a concentration range $1-100 \mathrm{ng} / \mathrm{j} \mathrm{L}$. The scope of this investigation did not permit the evaluation of total-ion and single-ion areas as a function of concentration for a large number of compounds, hence model species were used to estimate concentration values. Benzonitrile is an example of a neutral-fraction compromise-model compound; its mass spectrum is typical of unsubstituted or singly substituted aromatic. compounds, it has medium polarity, and it is present in the influent fractions. Limited studies were done on other organic compounds, used as models for purposes of estimation of concentration levels, with phenol, cresol, xylene, trimethy1pyridine, ethylphenol, naphthalene, anthracene, acridine, and carbazole. Since removal efficiencies were estimated by comparing total ions of the same compound, removal efficiencies are reported with greater confidence than concentration values.

The :assumption of uniform extraction efficiency is probably the least substantiated. Recovery studies for 16 standard compounds from distilled 


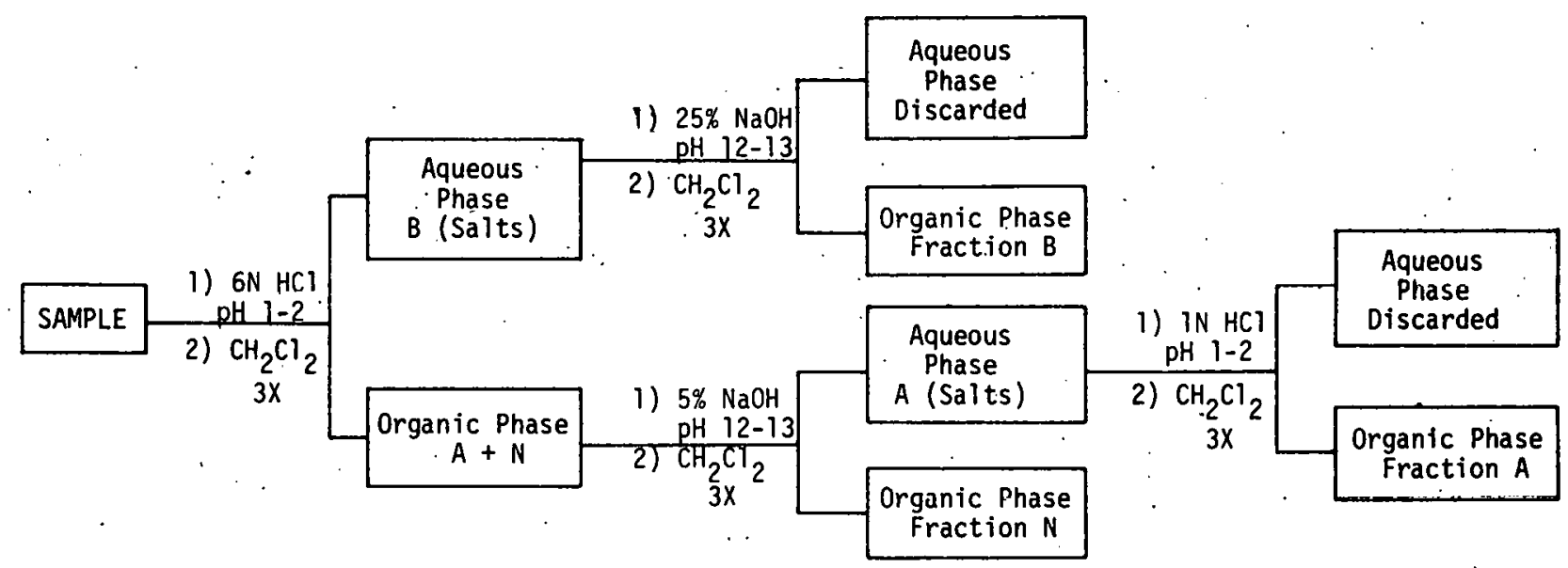

Fig. 1. Extraction Scheme for Biological Reactor. Influent and Effluents Samples

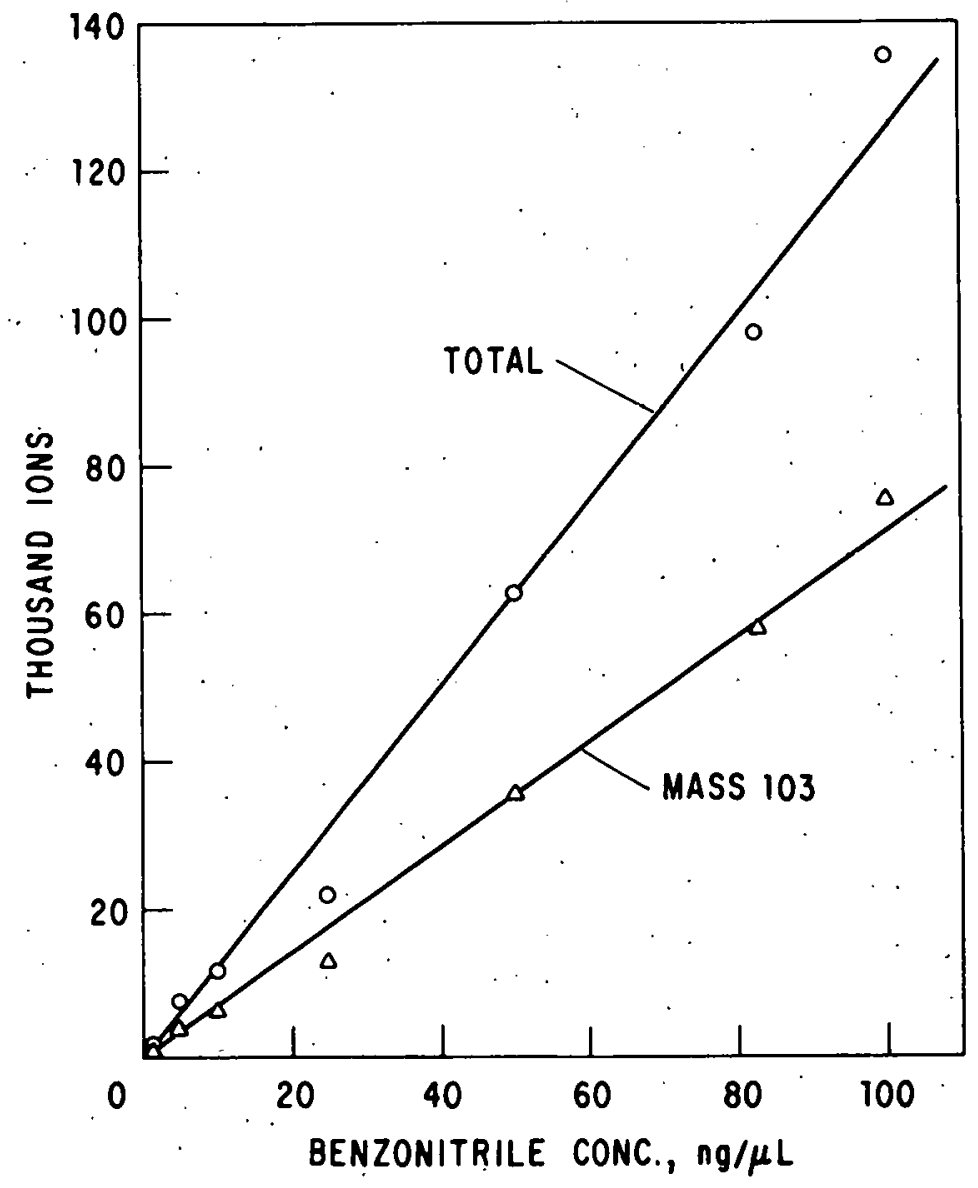

Fig. 2. Plot of Total-Ion and Single-Ion (Mass 103) Areas vs Concentration for Benzonitrile 
Table 2. Percent Recoveries of Organics Extracted from Spiked Distilled Water Based on GC Analysis

\begin{tabular}{lc}
\hline \multicolumn{1}{c}{ Compound } & \% Recovery \\
\hline o-Xylene & 65 \\
Mesitylene & 65 \\
3-Octanone & 85 \\
1-Heptanol. & 86 \\
n-Butylbenzene & 56 \\
Trimethylpyridine & 54 \\
Phenol & 82 \\
o-Cresol & 95 \\
o-Ethylphenol & 105 \\
Naphthalene & 68 \\
Dimethylnapthalene & 91 \\
Anthracene & 99 \\
d. -Anthracene & 102 \\
Acridine & 78 \\
Carbazole & 101 \\
Pyrene & 105 \\
\hline Average for 16 compounds & 84 \\
\hline
\end{tabular}

water are presented in Table 2: These data show that recoveries of the organics varied considerably, from 54 to $105 \%$, with an average value of $84 \%$. Furthermore, it is known that concentration levels (Warner, 1976), matrix effects, and the extent of emulsion in extraction affect solvent extraction yields. Nonetheless, since the scope of this study was to estimate only percent removals of organic constituents, the assumption of uniform extraction yield was followed, using a convenient procedure. It is planned to evaluate recovery efficiencies of organics in coal-gasification quench water samples in future work.

\section{EXPERIMENTAL RESULTS}

\subsection{BIOLOGICAL REACTOR CHARACTERISTICS}

Táble 3 summarizes general operating parameter and performance characteristics for the blological reactors employed for evaluation of the removal efficlencies of organic constituents. 
Results. for the HYGAS study show that the reactor used gave good removal efficiencies for COD, phenolics, and thlocyanate. The reactor possessed typical values of MLVSS and demonstrated good sludge sett1ing propeties, The reactor operating conditions resulted in a COD removal rate of 0.86 day $^{-1}$. These parameters are similar to those that may be envisioned for a commercial facility, although a commercial facility may be designed for a lower COD-removal rate, depending on the degree of conservatism.

Comparison of operating parameters for treatment of. $33 \%$-strength SFB quench water shows similar values of mean-cell residence time and steady-state value of MLVSS as employed in the HYGAS study. However, the SFB reactor was operated at longer hydraulic residence time, which resulted in a lower COD removal rate, 0.37 date $e^{-1}$. Data in Table 3 show excellent removal efficiencies for primary constituents and illustrate that a high degree of nitrification was achieved. The average concentration of SFB-effluent phenolic compounds was $1 \mathrm{mg} / \mathrm{L}$ or less as measured by the 4-amino-antipyrine colorimetric procedure. As shown below, GC/MS analysis of a composite sample of SFB biological reactor effluent gave a lower average concentration of specific phenolic compounds. Refer to Luthy and Tallon (1978) and Luthy et al. (1979) for additional information on operating characteristics of biological reactors.

\subsection{REMOVAL EFFICIENCY OF ORGANIC COMPOUNDS}

Total-ion chromatograms of the acid, base, and neutral fractions of the HYGAS and SFB biological reactor influent and effluent are presented in Figs. 3 to 5. Visual comparison of the chromatograms reveals that activated-sludge treatment removed the bulk of the organic constituents.

Estimated influent and effluent concentrations and percentage removal of major extractable and chromatographable organic compounds identified in the acid, base, and neutral fractions are presented in. Tables 4 to 6 . Since concentration levels were estimated on the basis of total-ion peak areas referenced to several standard compounds, and because of possible losses due to extraction and separation procedures, it is believed that reported concentration levels are only semiquantitative estimates $( \pm 33-50 \%)$. Percent removal values are considered more accurate than concentration values because these estimates are based on comparison of total ion counts assuming similar extraction efficiencies for reactor influent and effluent.

\section{DISCUSSION.}

\subsection{ACID FRACTIONS}

As shown in Table 4, the acid fractions of both the HYGAS and SFB quench water influents were composed almost exclusively of phenol and singlering alkylated phenollc compounds. Phenol and cresols constituted the largest fraction of observed organics: The acid influent fraction represented more than $98.5 \%$ of total identified organics on a mass basis for the HYGAS sample, and more than $99.3 \%$ for the SFB sample. Despite the abundance of these compounds in the influent, only traces of a.cresol were detected in the HYGAS 
Table 3. Average Biological Reactor Performance Data for Evaluation of Removal of Trace Organic Compounds ${ }^{a}$

\begin{tabular}{|c|c|c|c|c|c|}
\hline Parameter ${ }^{\mathrm{b}}$ & & \multicolumn{2}{|c|}{$\begin{array}{c}\text { HYGAS }^{c} \\
\text { Wast ewater }\end{array}$} & \multicolumn{2}{|c|}{$\begin{array}{c}\mathrm{SFB}^{\mathrm{d}} \\
\text { Wast ewater }\end{array}$} \\
\hline Mean Cell Residence Time, days & & \multicolumn{2}{|c|}{15} & \multicolumn{2}{|c|}{15} \\
\hline Hydraulic Residence Time, dáys & & \multicolumn{2}{|c|}{2.05} & \multicolumn{2}{|c|}{9.2} \\
\hline COD Removal Rate, days ${ }^{-1}$ & & \multicolumn{2}{|c|}{0.86} & \multicolumn{2}{|c|}{0.37} \\
\hline Mixed Liquor Suspended Solids, MLS & & \multicolumn{2}{|c|}{2000} & \multicolumn{2}{|c|}{1870} \\
\hline Mixed Liquor Volatile Sus. Solids, & MLVSS & \multicolumn{2}{|c|}{1820} & \multicolumn{2}{|c|}{1500} \\
\hline $\mathrm{O}_{2}$ Util. Rate, $\mathrm{mg} \mathrm{O}_{2} / \mathrm{mg}$ MLVSS-day & & \multicolumn{2}{|c|}{0.28} & \multicolumn{2}{|c|}{0.33} \\
\hline Zone Settling Velocity, ft/hr & & \multicolumn{2}{|c|}{24} & \multicolumn{2}{|c|}{15} \\
\hline \multirow[t]{2}{*}{ Sludge Volume Index, $\mathrm{mL} / \mathrm{g}$ MLSS } & & \multicolumn{2}{|c|}{54} & \multicolumn{2}{|c|}{39} \\
\hline & & $\underline{\operatorname{In} f}$ & $\underline{\text { Eff }}$ & $\underline{\operatorname{Inf}}^{c}$ & $\underline{E f f}^{C}$ \\
\hline COD & $\cdot$ & 3710 & 710 & 6780 & 1260 \\
\hline Phenolics & & 625 & $0.3^{e}$ & 1510 & 1 \\
\hline $\mathrm{NH}_{3}-\mathrm{N}$ & $\because$ & 148 & 101 & 157 & 17 \\
\hline $\mathrm{NO}_{3}-\mathrm{N}$ & & -- & 2 & $<2$ & 160 \\
\hline Org-N & & 10 & 7 & 43 & 21 \\
\hline $\mathrm{CN}_{\text {tot }}^{-}$ & . & 0.4 & 0.4 & 0.5 & 0.9 \\
\hline $\mathrm{SCN}^{-}$ & & 12 & 2 & 16 & 2 \\
\hline$s^{2}-$ & & $<10$ & $<6$ & 4 & $<3$ \\
\hline Suspended $O i 1$ and Grease & & -- & -- & $<10$ & $<10$ \\
\hline Alkalinity (as $\mathrm{CaCO}_{3}$ ) & & 710 & 260 & 1240 & 560 \\
\hline Conductivity $(\mu \mathrm{mhos} / \mathrm{cm})$ & & 4500 & 5900 & 3740 & 4520 \\
\hline
\end{tabular}

${ }^{a}$ Refer to Section 2.1 for limitations on data interpretation.

${ }^{b}$ All units in $\mathrm{mg} / \mathrm{L}$ except as noted.

${ }^{c}$ Ammonia stripped wastewater. Data source: Luthy and Tallon (1978).

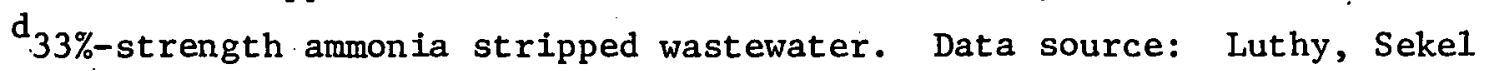
and Tallon (1979).

eAverage value during the period of sample collection for trace organic analysis was $<0.05 \mathrm{mg} / \mathrm{L}$. 


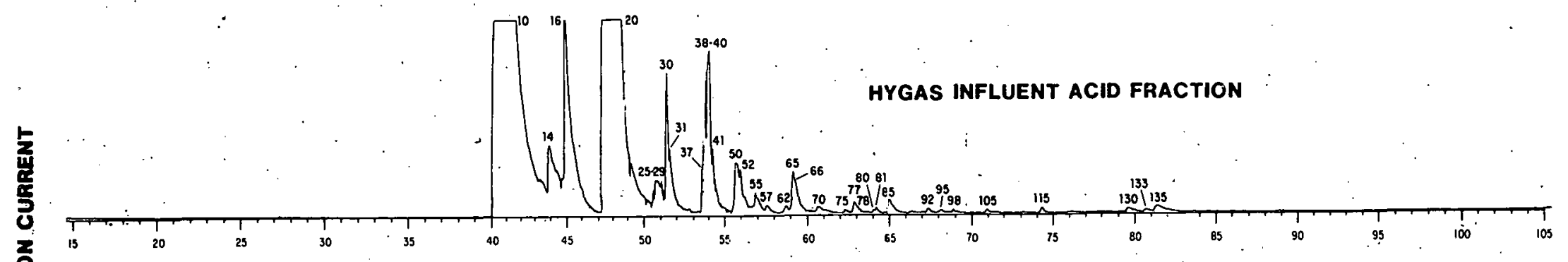

HYGAS EFFLUENT ACID FRACTION (X 20)
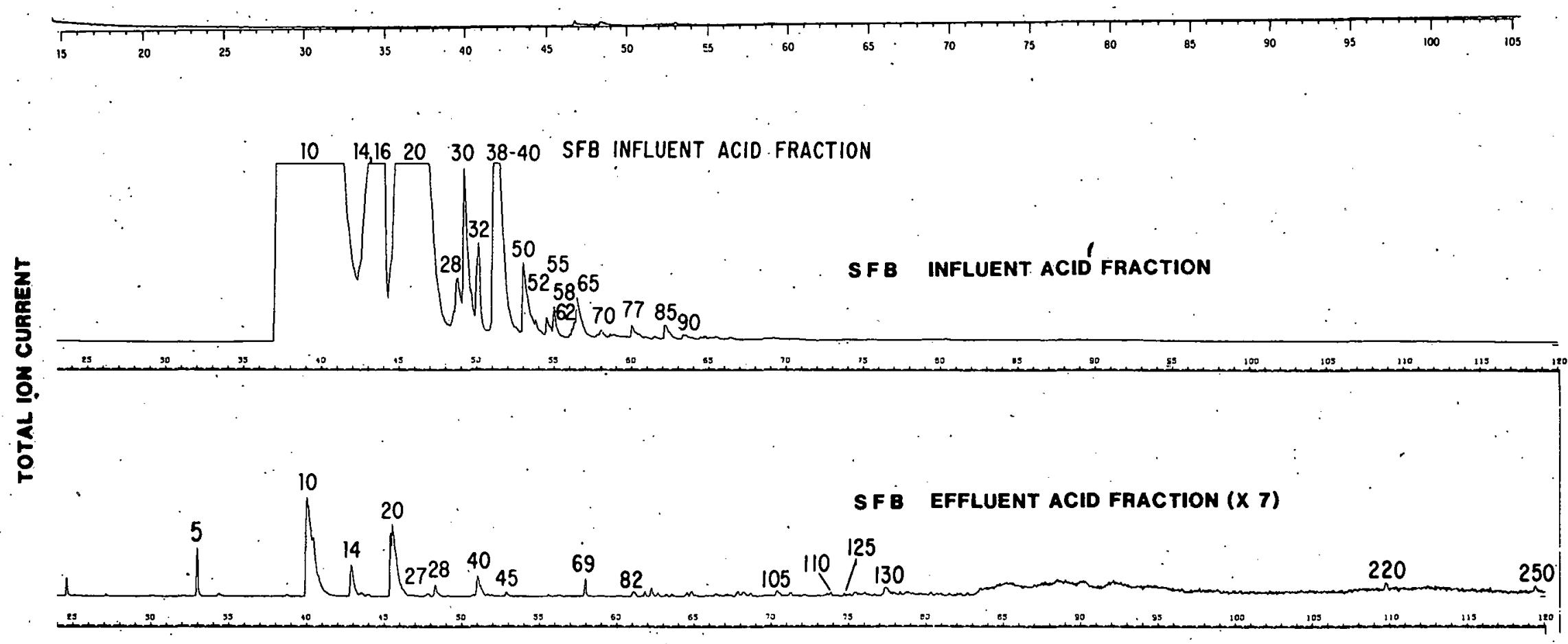

RETENTION TIME, MIN:

Fig. 3. Total-Ion Chromatograms of Influent and Effluent Acid-Fraction Extracts of Biologically Treated HYGAS and SFB Quench Waters 

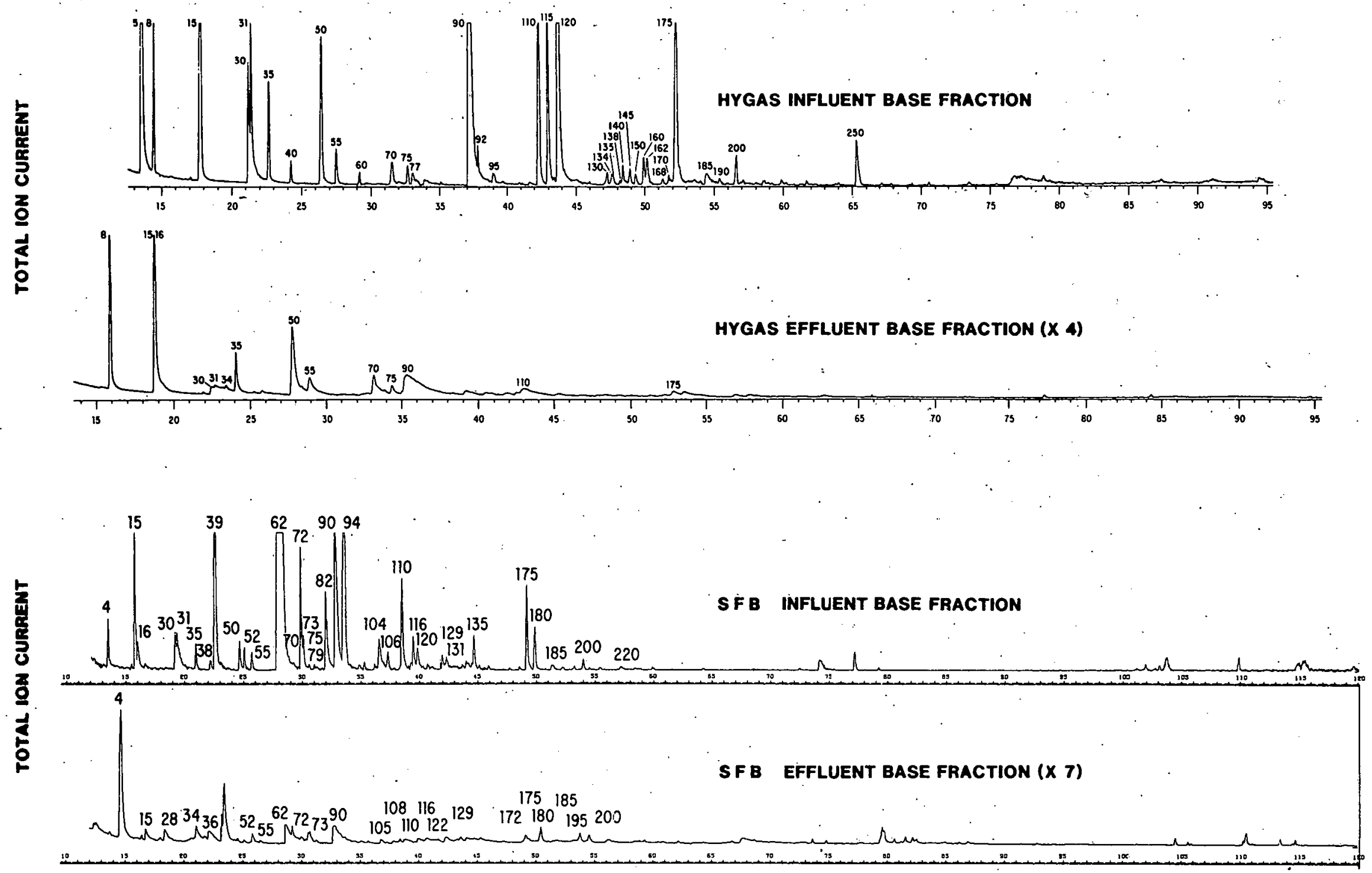

RETENTION TIME, MIN.

Fig. 4. Total-Ion Chromatograms of Influent and Effluent Base-Fraction Extracts of Biologicaliy Treated HYGAS and SFB Quench Waters 

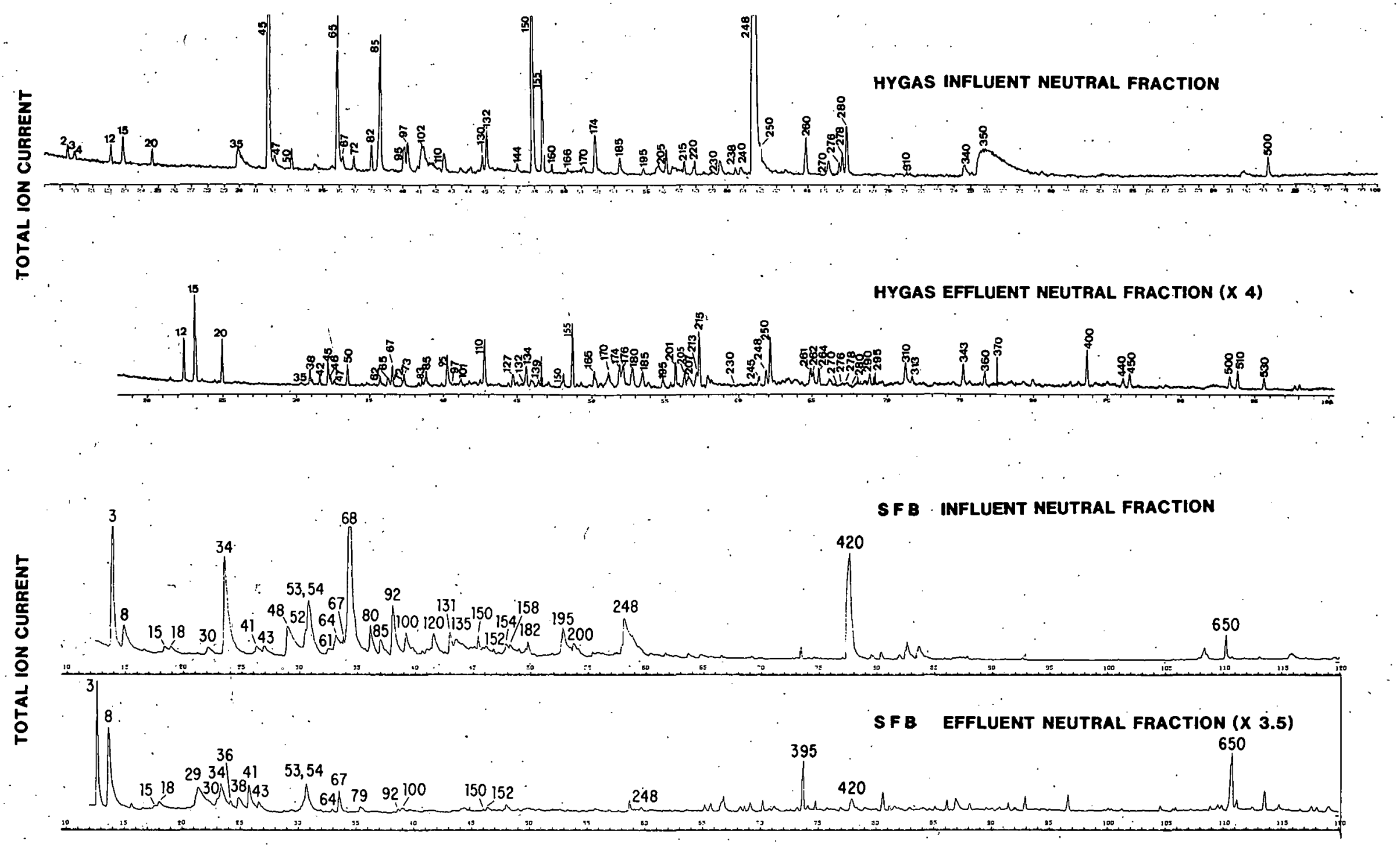

RETENTION TIME, MIN.

Fig. 5. Total-Ion Chromatograms of Influent and Effluent Neutral-Fraction Extracts of Biologically Treated HYGAS and SFB Quench Waters 
Table 4. Concentration of Acid-Fraction Organic Constituents in Influent and Effluent Quench Waters by Activated-Sludge at Bench Scale, Together with the Percent Removal Values ${ }^{a}$

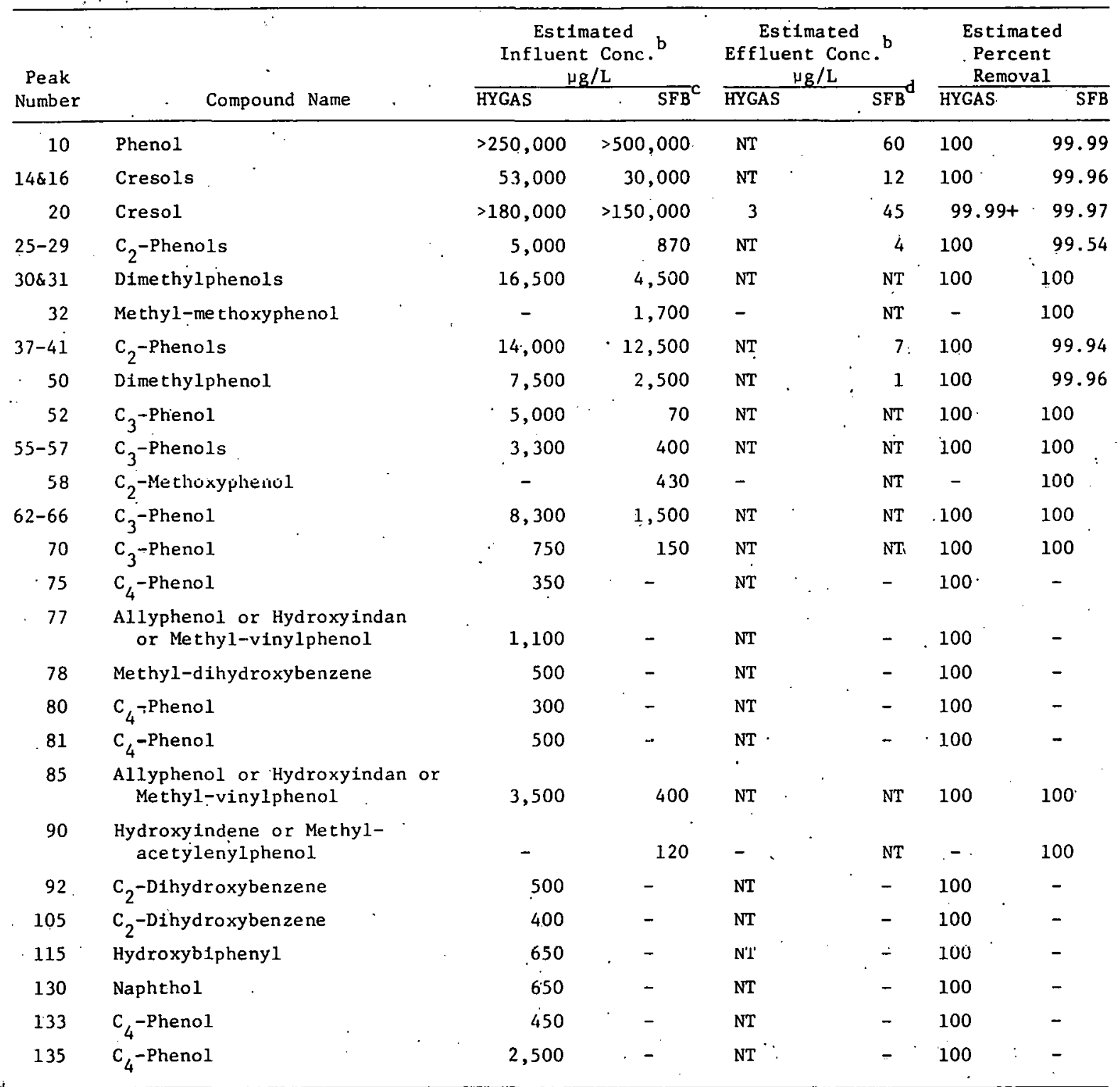

aefer to section on sample representativeness for limitation on data

interpretation.

$b_{\mathrm{NT}}$, not detected. $100 \%$ removal means that the compound was below detection limits.

Undiluted ammonia-stripped quench-water concentrations reported here for comparative purposes. This sample was diluted to $33 \%$ strength for efficient dbiological treatment.

Actual blological reactor effluent concentrations were multiplied by 3 as reported here to factor our apparent removal owing to dilution. Thus all

- SFB effluent concentrations are normalized to an undiluted basis. 
Table 5. Concentration of Base-Fraction Organic Constituents in Influent and Effluent Quench Waters by Activated-Sludge at Bench Scale, Together with the Percent Removal Values ${ }^{a}$

\begin{tabular}{|c|c|c|c|c|c|c|c|}
\hline \multirow{2}{*}{$\begin{array}{c}\text { Peak } \\
\text { Number }\end{array}$} & \multirow{2}{*}{ Compound Name } & \multicolumn{2}{|c|}{$\begin{array}{c}\text { Estimated } \\
\text { Influent Conc. } \\
\mu \mathrm{g} / \mathrm{L}\end{array}$} & \multicolumn{2}{|c|}{$\begin{array}{c}\text { Estimated } \\
\text { Effluent Conc. } \\
\mu \mathrm{g} / \mathrm{L} \\
\end{array}$} & \multicolumn{2}{|c|}{$\begin{array}{c}\text { Estimated } \\
\text { Percent } \\
\text { Removal } \\
\end{array}$} \\
\hline & & HYGAS & $\overline{\mathrm{SFB}} \mathrm{c}$ & $\overline{\mathrm{HYGAS}}$ & $\overline{S F B} d$ & HYGAS & $\mathrm{SFB}$ \\
\hline 4 & Methyl tetrazole? & -- & 21 & -- & 20 & -- & 5 \\
\hline 5 & Pyridine & 540 & - & IT & -- & 100 & -- \\
\hline 15 & Picoline & 310 & 76 & 160 & 2 & 48 & 97 \\
\hline 16 & Methyldiazine & -- & 20 & -- & NT & - & 100 \\
\hline $30 \& 31$ & Picolines & 290 & 65 & 25 & $\mathrm{NT}$ & 92 & 100 \\
\hline 34 & $\mathrm{C}_{2}$-Imidazole or $\mathrm{C}_{2}$-Pyrazole & -- & ND & -- & 3 & -- & $\mathrm{ND} / \mathrm{PR}$ \\
\hline 35 & Ethylpyridine & 75 & 14 & 32 & NT & 57 & 100 \\
\hline 36 & $\mathrm{C}_{2}$-Imidazole or $\mathrm{C}_{2}$-Pyrazole & -- & ND & -- & 3.5 & -- & $\mathrm{ND} / \mathrm{PR}$ \\
\hline 38 & $C_{2}$-Diazine & -- & 7 & -- & 2 & -- & 71 \\
\hline 39 & Ethylimidazole or Ethylpyrazole & -- & 185 & -- & 10 & -- & 95 \\
\hline 40 & Dimethylpyridine & 14 & -- & NT & - & 100 & -- \\
\hline 50 & $\mathrm{C}_{2}$-Pyridine & 150 & - 16 & $95^{\circ}$ & NT & 37 & 100 \\
\hline 52 & $\mathrm{C}_{3}$-Imidazole or $\mathrm{C}_{3}$-Pyrazole & -- & 10 & - & 0.9 & -- & 91 \\
\hline 55 & $\mathrm{C}_{2}$-Pyridine & 31 & 9 & 28 & NT & 10 & 100 \\
\hline 60 & $\mathrm{C}_{3}$-Pyridine & 9 & -- & NT & -- & 100 & -- \\
\hline 62 & $\mathrm{C}_{1}$-Aminopyrrole & -- & 1,050 . & -- & 5 & - & 99.5 \\
\hline 70 & $\dot{c}_{3}$-Pyridine & 30 & -- & 28 & - & 7 & $\therefore$ \\
\hline 72 & $\mathrm{C}_{3}$-Imidazole or $\mathrm{C}_{3}$-Pyrazole & -- & 64 & -- & 1 & -- & 98.5 \\
\hline 73 & $\mathrm{C}_{3}$-Imidazole or $\mathrm{D}_{3}$-Pyrazole & -- & 19 & -- & 1 & -- & 95 \\
\hline 7.5 & $\mathrm{C}_{3}$-Pyridine & 15 & -- & 8 & - & 47 & $\therefore$ \\
\hline 77 & Acetylenyl pyridine & 14 & -- & NT & - & 100 & -- \\
\hline 82 & $\begin{array}{l}\mathrm{C}_{3} \text {-Imidazole or } \mathrm{C}_{3} \text {-Pyrazole } \\
\text { or } \mathrm{C}_{2} \text {-Aminopyrrole }\end{array}$ & -- & 68 & -- & $<1$ & $\therefore$ & 98.5 \\
\hline 90 & Aniline & 2,000 & 180 & 105 & 10 & 95 & 94.5 \\
\hline 92 & $\mathrm{C}_{4}$-Pyridine & $<10$ & -- & $\mathrm{NT}$ & -- & 100 & - \\
\hline 94 & $\begin{array}{l}\mathrm{C}_{3} \text {-Imidazole or } \mathrm{C}_{3} \text {-Pyrazole } \\
\text { or } \mathrm{C}_{2} \text {-Aminopyrrole }\end{array}$ & - & 270 & -- & $<0.5$ & -- & 99.8 \\
\hline 104 & $\begin{array}{l}\mathrm{C}_{3} \text {-Imidazole or } \mathrm{C}_{3} \text {-Pyrazole } \\
\text { or } \mathrm{C}_{2} \text {-Aminopyrrole }\end{array}$ & - & 34 & - & NT & - & 100 \\
\hline 105 & Me thoxyaniline & -- & $\mathrm{ND}$ & -- & $<1$ & -- & $\mathrm{ND} / \mathrm{PR}$ \\
\hline 106 & $\begin{array}{l}\mathrm{C}_{4}-\text { Imidazole or } \mathrm{C}_{4}-\text { Pyrazole } \\
\text { or } \mathrm{C}_{3} \text {-Aminopyrrole }\end{array}$ & - & 10. & - & NT & -- & 100 \\
\hline 110 & Methylaniline & 250 & 58 & 28 & 0.5 & 89 & $99+$ \\
\hline 112 & Methoxyanlline & - & ND & -- & 0.5 & - & ND/PR \\
\hline 115 & Methylaniline & 180 & -- & NT & $\therefore$ & 100 . & - \\
\hline 116 & Methoxyantline & -+ & 22 & -- & 1 & -- & 95 \\
\hline 120 & Methylaniline & 510 & 21 & NT & NT & 100 & 100 \\
\hline
\end{tabular}


Table 5 (Contd.)

\begin{tabular}{|c|c|c|c|c|c|c|c|c|}
\hline \multirow{2}{*}{$\begin{array}{c}\text { Peak } \\
\text { Number }\end{array}$} & \multirow[b]{2}{*}{ Compound } & \multirow[b]{2}{*}{ Name } & \multicolumn{2}{|c|}{$\begin{array}{c}\text { Estimated } \\
\text { Influent Conc. } \\
\mu \mathrm{g} / \mathrm{L}\end{array}$} & \multicolumn{2}{|c|}{$\begin{array}{c}\text { Estimated } \\
\text { Effluent Conc. } \\
\mu \mathrm{g} / \mathrm{L} \\
\end{array}$} & \multicolumn{2}{|c|}{$\begin{array}{l}\text { Estimated } \\
\text { Percent } \\
\text { Removal }\end{array}$} \\
\hline & & & HYGAS & $\overline{\mathrm{SFB}}$ & $\overline{\text { HYGAS }}$ & $\overline{\mathrm{SFB}}$ & HYGAS & $\overline{\mathrm{SFB}}$ \\
\hline 129 & Methoxyaniline & & -- & 10 & -- & 1.5 & -- & 85 \\
\hline $134 \& 135$ & $C_{2}$-Aniline $\& C_{4}-P y$ & ridine & 15 & - & NT & -- & 100 & - \\
\hline 135 & $\mathrm{C}_{4}$-Pyridine & . & - & 26 & - & 0.4 & $\therefore$ & 98.5 \\
\hline 140 & $C_{2}$-Aniline & & 15 & - & NT & -- & 100 & -- \\
\hline 145 & $\mathrm{C}_{2}$-Aniline & & 12 & -- & NT & -- & 100 & -- \\
\hline 150 & $\mathrm{C}_{2}$-Aniline & & 11 & -- & NT & -- & 100 & -- \\
\hline .160 & $\mathrm{C}_{2}$-Aniline & & 28 & -- & NT & -- & 100 & -- \\
\hline 162 & $\mathrm{C}_{2}$-Aniline & & 31 & $\therefore$ & NT & -- & 100 & -- \\
\hline 168 & $c_{2}$-Aniline & . & 9 & -- & NT & -- & 100 & -- \\
\hline 170 & $\mathrm{C}_{2}$-Aniline & . & 10 & -- & NT & -- & 100 & -- \\
\hline 175 & Quinoline & & 280 & 57 & 9 & NT & 97 & 100 \\
\hline 180 & $\mathrm{C}_{5}$-Pyridine & & -- & 25 & -- & 2 & -- & 92 \\
\hline 185 & Isoquinoline & & 24 & 6 & NT & NT & 100 & 100 \\
\hline 200 & Methylquinoline & & 28 & 7 & 3 & $i$ & 90 & 83 \\
\hline 205 & Indole & & 60 & - & NT & $\therefore$ & 100 & - \\
\hline
\end{tabular}

a See. notes under Table 4 .

ND/PR, not determinable/poorly removed. See note under Table 6 .

effluent and only very small amounts of phenol and cresols were detected in the SFB effluent. The SFB effluent chromatogram (Fig. 3) showed a series of fine structure peaks in the retention time range of $55-80 \mathrm{~min}$, corresponding to either alkylated phenols or alkylated hydroxyindans with olefinic substitutions.

\subsection{BASE FRACTIONS}

Table 5 shows that organics in the HYGAS basic influent fraction were primarily nitrogen heterocyclics (pyridine, quinoline, indole), as weli as aniline and its alkylated derivatives. Most of the basic compounds were removed either completely or quite effectively, with the exception of certain alkylated pyridines.

The basic influent fraction of the SFB sample consisted largely of aniline, methoxyanilines, alkylated anilines, and a series of nitrogen heterocyclic compounds (viz., alkylated aminopyrroles, imidazoles and/or pyrazoles, and diazines), as well as the other compounds mentioned above. In general, removal efficiencies for these compounds were very good. The overall removal efficiency for base-fraction organics was over $90 \%$ in the HYGAS sample and over $96 \%$ in the. SFB sample. 
Table 6: Concentration of Neutral-Fraction Organic Constituents in Influent and Effluent Quench Waters by Activated-Sludge at Bench Scale, Together with the Percent Removal Values ${ }^{a}$

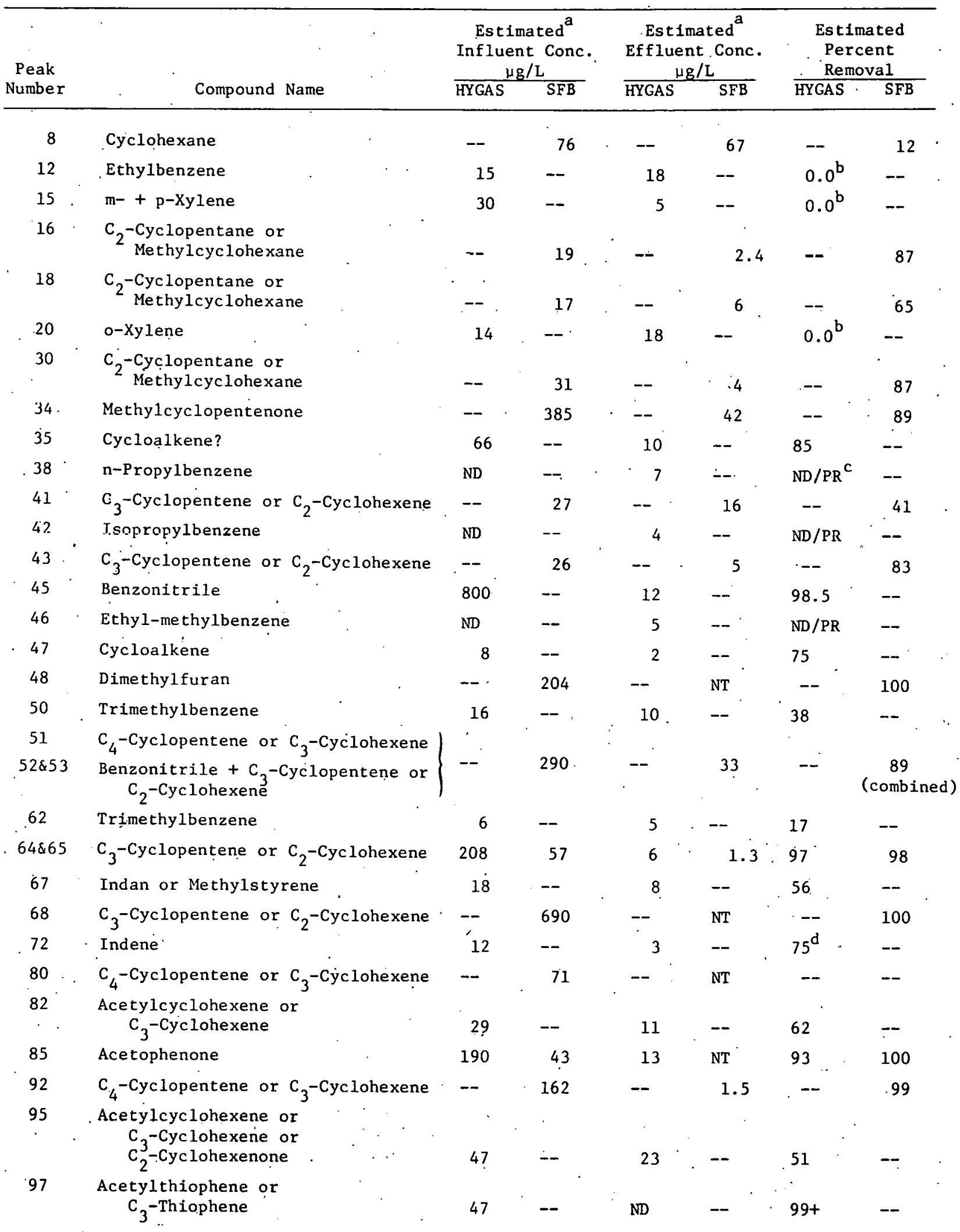


Table 6 (Contd.)

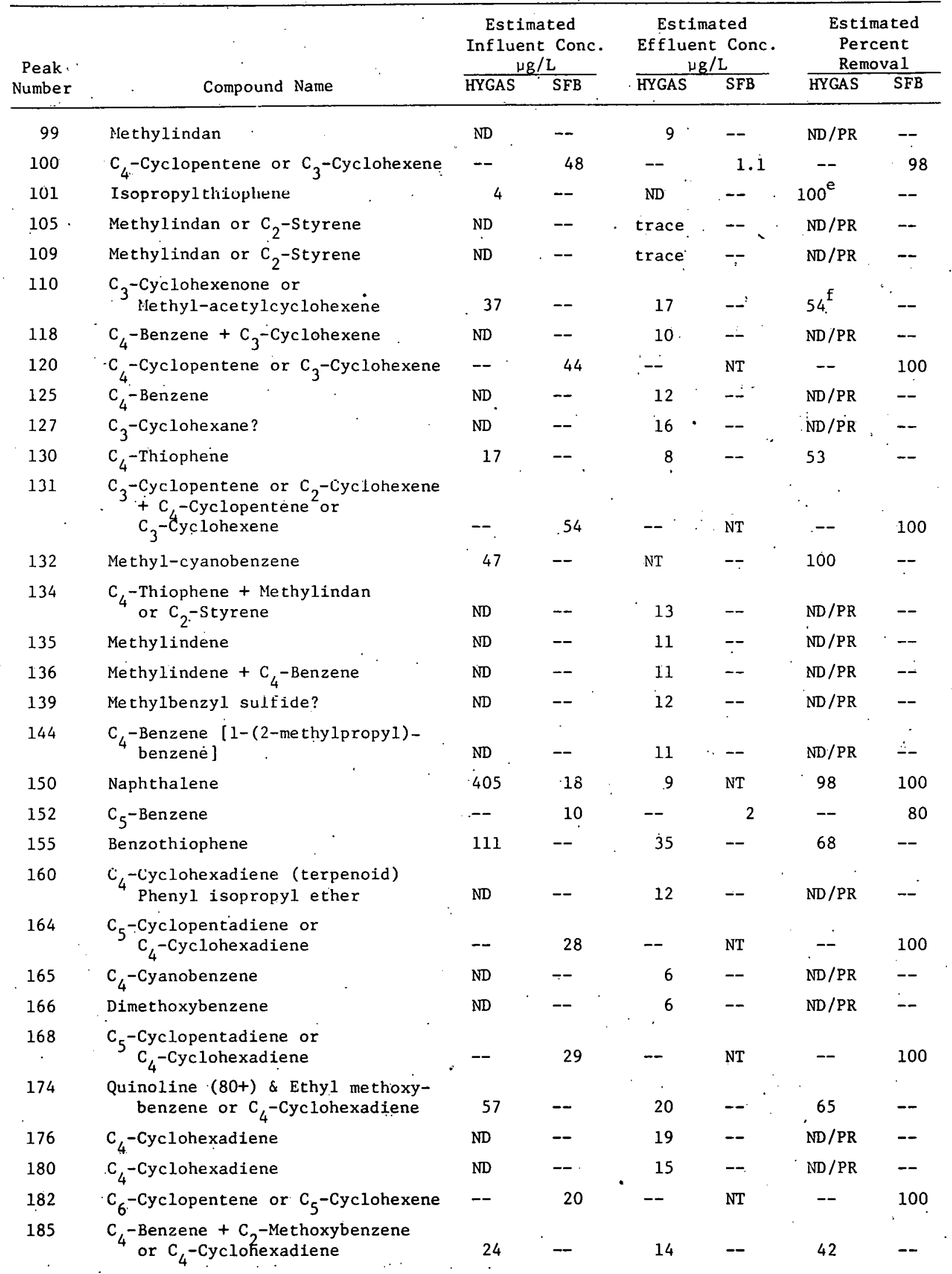


Table 6 (Contd.)

\begin{tabular}{|c|c|c|c|c|c|c|c|c|c|}
\hline \multirow{2}{*}{$\begin{array}{l}\text { Peak } \\
\text { Number }\end{array}$} & \multirow[b]{2}{*}{ Compound Name } & & & \multicolumn{2}{|c|}{$\begin{array}{c}\text { Estimated } \\
\text { Influent Conc. } \\
\mu \mathrm{g} / \mathrm{L}\end{array}$} & \multirow{2}{*}{\multicolumn{2}{|c|}{$\begin{array}{c}\begin{array}{c}\text { Estimated } \\
\text { Effluent Conc. } \\
\frac{\mu \mathrm{g} / \mathrm{L}}{\text { HYGAS SFB }}\end{array}\end{array}$}} & \multicolumn{2}{|c|}{$\begin{array}{c}\text { Estimated } \\
\text { Percent } \\
\text { Removal } \\
\end{array}$} \\
\hline & & & & HYGAS & $\overline{S F B}$ & & & $\overline{\text { HYGAS }}$ & SFB \\
\hline 194 & $\begin{array}{c}\mathrm{C}_{6}=\text { - Cyclopentadiene or } \\
\mathrm{C}_{5} \text {-Cyclohexadiene }\end{array}$ & & & $-\stackrel{-}{2}$ & 100 & -- & NT & -- & 100 \\
\hline 195 & Indanone & & $\cdot$ & $\mathrm{ND}$ & -- & $\therefore 7$ & -- & $\mathrm{ND} / \mathrm{PR}$ & -- \\
\hline 200 & $\begin{array}{c}\mathrm{c}_{6} \text {-Cyclopentadiene or } \\
\mathrm{C}_{5} \text {-Cyclohexadiene }\end{array}$ & & & - & 29 & -- & $\mathrm{NT}$ & - & 100 \\
\hline 201 & Methyl-benzothiophene & $\cdot$ & & ND & -- & 11 . & -- & $\mathrm{ND} / \mathrm{PR}$ & -- \\
\hline 205 & 2-Me thylnaphthalene & & & 23 & -- & 9 & $\therefore$ & 61 & -- \\
\hline 207 & $\mathrm{C}_{5}$-Cyclohexadiene & & & $\mathrm{ND}$ & -- & trace & - & $\mathrm{ND} / \mathrm{PR}$ & $\because$ \\
\hline 213 & Methyl-benzothiophene & & & $\mathrm{ND}$ & - & 22 & -- & $\mathrm{ND} / \mathrm{PR}$ & -- \\
\hline 215 & 1-Methylnaphthalene & & & ND & -- & 24 & -- & $\mathrm{ND} / \mathrm{PR}$ & - \\
\hline 219 & $\begin{array}{c}\text { Isopropyl-me thoxybenzene } \\
C_{5} \text {-Cyclohexadiene }\end{array}$ & e or & . &. .16 & -- & 9 & -- & 44 & -- \\
\hline 220 & $c_{3}$-Methoxybenzene & & & ND. & - & NT & -- & $\mathrm{ND} / \mathrm{PR}$ & -- \\
\hline 230 & Indazole or Benzimidazo & ole & & 29 & -- & NT & -- & 100 & $\because$ \\
\hline 238 & $\begin{array}{c}\text { n-propyl-methoxybenzene } \\
\mathrm{C}_{5} \text {-Cyclohexadiene }\end{array}$ & er & & 5 & -- & $\begin{array}{c}: \\
\text { trace }\end{array}$ & -- & $99+$ & - \\
\hline 240 & $\begin{array}{c}\mathrm{C}_{3} \text {-Methoxybenzene or } \\
\mathrm{C}_{5} \text {-Cyclohexadiene }\end{array}$ & & & 6 & -- & trace & -- & $99+$ & -- \\
\hline $245^{\circ}$ & Ethyl benzoate & & & $\therefore$ & -- & 6 & -- & $+^{8}$ & -- \\
\hline 248 & Indole & & & 1,980 & 270 & 8 & 2 & 99.5 & 99.3 \\
\hline 250 & Bipheny $1^{\circ}$ & & & 10 & -- & 3. & -- & 70 & -- \\
\hline 260 & Methylindole & & & 50 & -- & NT & -- & 100 & - \\
\hline 261 & $\mathrm{C}_{2}$-Naphthalene & & & ND & -- & 10 & -- & $\mathrm{ND} / \mathrm{PK}$ & -- \\
\hline 262 & $\mathrm{C}_{2}$-Naphthalene & & & ND & -- & 7 & -- & $\mathrm{ND} / \mathrm{PR}$ & -- \\
\hline 264 & Methylbipheny 1 & & & ND & -- & 9 &.- & $\mathrm{ND} / \mathrm{PR}$ & -- \\
\hline 270 & Methylindole & & & 26 & $-\dot{0}$ & trace & -- & 99+ & -- \\
\hline 276 & Methylindole & & & 15 & -- & NT & -- & 100 & -- \\
\hline 278 & Methylindole & & ? & $25^{\circ}$ & -- & NT & -- & 100 & - \\
\hline 280 & Methylindole & & & 65 & -- & NT & -- & 100 & -- \\
\hline 290 & Acenaphthene & & & $\mathrm{ND}$ & $-\div$ & 7 & -- & $\mathrm{ND} / \mathrm{PR}$ & -- \\
\hline 295 & Methylbiphenyl & & & ND & - & 7 & -- & ND/PR & -- \\
\hline 310 & $\mathrm{c}_{6}$-Theophene + Methylbi & iphenyl & & ND & -- & 8 & $\because$ & $\mathrm{ND} / \mathrm{PR}$ & -- \\
\hline 311. & Bibenzyl & & & $\mathrm{ND}$ & -- & 7 & - & $\mathrm{ND} / \mathrm{PR}$ & -- \\
\hline 313 & $\mathrm{C}_{6}$-Thiophene & & & ND & -- & 4 & $\therefore-$ & $\mathrm{ND} / \mathrm{PR}$ & -- \\
\hline 340 & n-Propylnaphthalene & & & .7 & - & NT & -- & $98+$ & - \\
\hline 343 & Fluorene & & 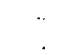 & ND & -- & 17 & -- & $\mathrm{ND} / \mathrm{PR}$ & -- \\
\hline $350-355$ & Cyanophenyl benzoate? & $\& ?$ & & 68 & -- & NT . & -- & 100 & -- \\
\hline 370 & Plasticizer & & & -- & -- & & -- & $t^{g}$ & -- \\
\hline 400 & Aliphatic Hydrocarbon & & & ND & -- & 6 & -- & $\mathrm{ND} \cdot / \mathrm{PR}$ & -- \\
\hline 420 & Unknown & & & -- & 440 & -- & NT & -- & 100 \\
\hline
\end{tabular}


Table 6 (Contd.)

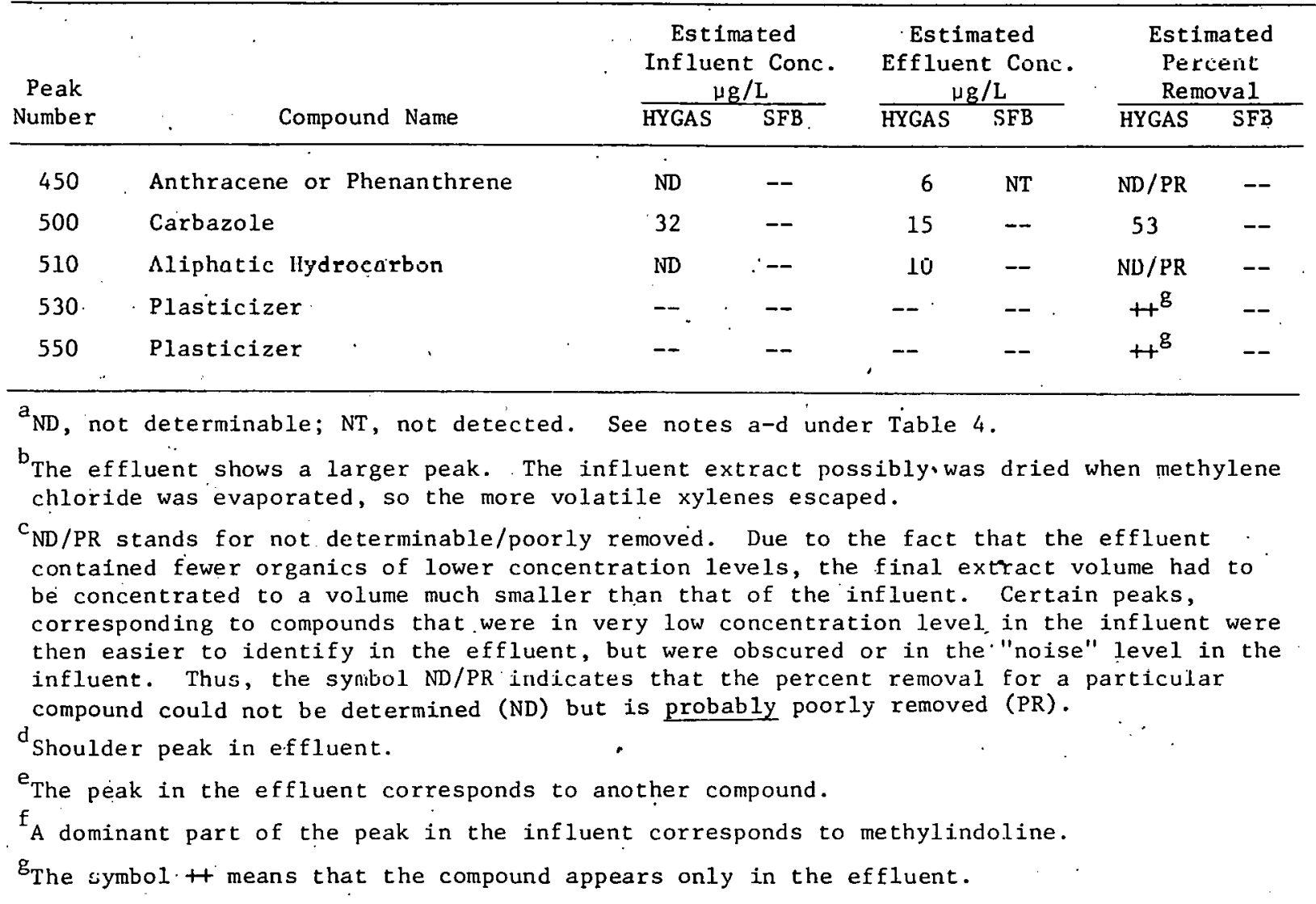

\subsection{NEUTRAL ERACTIONS}

Table 6 shows that neutral-fraction organics in the HYGAS sample cover a wide range of typical aromatic compounds, such as alkylated benzenes, indans, indenes, thiophenes, naphthalenes, benzothiophenes, bipheny1s, fluorene, acenaphthene, and anthracene or phenanthrene. Alkylated cycloalkanes, cycloalkenes, benzonitriles, indoles, acetophenone, and carbazole were also present. The SFB influent neutral-fraction lacked the variety of compounds observed in the HYGAS sample, as many of the common aromatic hydrocarbons were not observed. Principal species in the SFB neutral fraction were toluene, benzonitrile, acetophenone, naphthalene, indole, and alkylated cycloalkanes and cycloalkenes. Removal efficlency for SFB neutral-fraction organics was generally high except for certain alkylated cycloalkanes.

It was observed that for the HYGAS, sample the removal of neutralfraction organics was dependent on the chemical structure of the particular compound. The general trend was that heterocyclics and compounds containing heteratoms were usually removed effectively. Examples from the HYGAS sample (Table 4) are benzonftrile (peak No. 45), acetylthiophene (peak No. 97), isopropylthiophene (peak No. 101), methy1-cyanobenzene (peak No. 132), and methyl Indoles (peak Nos. 260, 270, 276, 278, 280). In the case of aromat1c hydrocarbons, a trend of less efficient removal for compounds with more alicylclc content was observed. Examples are substituted benzenes (peak Nos. $12,15,20,50,62$ ), cycloalkanes, and cycloalkenes (peak Nos. 35, 47, 67). 
Also, most of the compounds with the labels ND/PR (see Table 6, note C, and discussion below). fall into this category. Polynuclear aromatics were only partially removed, depending again on the amount of substitution. Examples are naphthalene (peak No. 150) vs substituted naphthalenes (peak Nos. 205, $215,261,262$ ), acenaphthene (peak No. 290), fluorene (peak No. 343), bibenzy1 (peak No. 311), and anthracene or phenanthrene (peak No. 450).

Compounds that were at very low concentrations in the influent fraction were obscured or in the "noise" level in the influent chromatogram. It was very difficult, if not impossible, therefore, to determine percent removal values for these compounds, even though it was easier to identify them in the effluent fraction, due to the fact that the effluent fraction was concentrated to a smaller volume $(0.5 \mathrm{~mL})$ than that of the influent ( $5 \mathrm{~mL})$. Such compounds are identified in Table 6 with the symbol ND/PR (not determinable/poorly removed) under the estimated-percent-removal column. The facts strongly suggest that these compounds, although in very low concentrations in the effluent, were poorly removed. This was also observed in the case of the base fraction of the SFB sample (Table 5). Some compounds such as ethyl benzoate (No. 245) and plasticizers (Nos. 370,530, 550) in Table 5 show up only in the effluent. Ethyl benzoate can be either a contaminant or an artifact; the presence of plasticizers probably reflects contamination from containers used for raw quench water storage and pretreatment. The SFB effluent chromatogram (Fig. 5) showed a series of peaks in the retention time range of 65-120 min. Most of these peaks could not be identified with certainty - some of them are attributed to plasticizers. In general, the overall removal of organics from the neutral fraction was over $86 \%$ efficient for the HYGAS sample and over $93 \%$ efficient for the SFB sample.

\section{CONCLUSIONS}

Quench waters from HYGAS and SFB pilot-plant, coal-gasification processes were treated biologically and samples of reactor influent and effluent were fractionated and analyzed for organic constituents. It was found that approximately $99 \%$ of extractable and chromatographable organic material, on a mass basis, was represented in the acid fraction of the influent coal-gasification process waters from HYGAS and SFB. Activatedsludge processing removed most of these organic.constituents. Compounds of the acid fractions were removed almost completely. Marked compositionál differences were found between the HYGAS and the SFB base and neutral fractions. These differences may be attributable to differences in coal type, gasifier operating conditions, and other process variables. High removal efficiencies were observed for compounds in the base fractions, with the exception of certain alkylated pyridines. The extent of removal of compounds in the neutral fractions was dependent on chemical structure. Most major components were removed effectively. Some aromatic hydrocarbons containing aliphatic substitutions and polynuclear aromatic compounds were only partially or poorly removed.

\section{RECOMMENDATIONS}

Analytical data presented in this study for organic characterizations are at best semiquantitative estimates. In future work it is necesary to 
address some of the unresolved questions regarding quantification of organic compounds in complex wastewaters. This work should include evaluation of extraction efficiencies for selected organic compounds from coal gasification process effluents. It is also recommended that special studies be performed for evaluation of removal efficiencies of polynuclear aromatic hydrocarbons. Finally, the fate of trace organic compounds during pretreatment also should be evaluated and a search should be made for improved removal efficiencies of refractory organics by various combinations of physicochemical and biological processes.

\section{ACKNOWLEDGMENTS}

We thank ANL scientists Wyman Harrison and Kenneth Wilzbach, John Craun of Environmental Research \& Technology, Inc., and Lou Anastasia of the Institute of Gas Technology for reviewing the entire manuscript. The Office of Fossil Energy Programs of the U.S. Department of Energy provided financial support.

\section{REFERENCES}

Ellman, R.C., L.E. Paulson, D.R. Hajicek, and T.G. Towers, Slagging Fixed-Bed Gasification Project Status at the Grand Forks Energy Technology Center; Presented at the 1979 Lignite Symposium, Grand Forks, North Dakota (May 30-31, 1979).

Jonardi, R.J., L.J. Anastasia, M.J. Massey, and R.H. Karst, Environmental Assessment of the HYGAS Process, Institute of Gas. Technology, Report to U.S. Department of Energy, Vo1. I, FE-2433-25 (1979).

Luthy, R.G., and J.T. Tallon, Experimental Analysis of Biological Oxidation Characteristics of HYGAS Coal Gasification Wastewater, Carnegie-Mellon University Report to U.S. Department of Energy, FE-2496-27 (1978).

Luthy, R.G., D.J. Sekel, and J.T. Tallon, Biological Treatment of Grand Forks Energy and Technology Center Slagging Fixed-Bed Coal Gasification Process Wastewater, Carnegie-Mellon University, Report to U.S. Department of Energy, FE-2496-42 (1979).

Raphaelian, L., and W. Harrison, Stability of Extractable Constituents in Stored Samples of Gasification Condensates Inferred From Comparisons of Total Ion Chromatograms, Argonne National Laboratory Report, ANL/EMR-3 (1979).

Singer, P.C., et al., Assessment of Coal Conversion Wastewaters: Characterization and Preliminary Biotreatability, U.S. EPA Report, EPA-600/778-181 (1978).

Stamoudis, V.C., R.G. Luthy, and W. Harrison, Removal of Organic Constituents in a Coal Gasification Process Wastewater by Activated Sludge Treatment, Argonne National Laboratory Report, ANL/WR-79-1 (1979). 
Ștamoudis, V.C., and R. G. Luthy, Biological Removal of Organic Constituents in Quench Water from A Slagging, Fixed-Bed Coal-Gasification Pilot Plant, Argonne National Laboratory Report, ANL/PAG-2 (1980).

Warner, J.S., Determination of Aliphatic and Aromatic Hydrocarbons in Marine Organisms, Anal. Chem., 48:578-583 (1976).

White, C.M., and C.E. Schmidt, Analysis of Volatile Polar Organics in Untreated By-Product Waters From Coal Conversion Processes, American Chemical Society, Div. of Fuel Chemistry, 23(2):134-143 (1978). 
Distribution for ANL/PAG-2

Internal
A. Antonopoulos
S. Bourne
R. P. Carter
E. J. Croke
P. Cunningham
S. Danyluk
J. D. Ditmars
J. Dzinge1
R. D. Flotard
D. Grahn
L. Habegger
J. Harkness

\author{
W. Harrison (10) \\ D. A. Haugen \\ L. J. Hoover \\ A. Jirka \\ D. O. Johnson \\ A. B. Krisciunas \\ K. S. Macal \\ W. E. Massey \\ D. L. McCown \\ E. G. Pewitt \\ L. A. Raphaelian \\ C. A. Reilly
}

J. J. Roberts

D. M. Rote

N. Sather

W. Sinclair

V. C. Stamoudis (40)

J. Stetter (10)

S. Vargo (10)

D-P Wang

K. Wilzbach (3)

ANL Contract Copy

ANL Libraries (5)

TIS. Files (6)

\section{External:}

DOE-TIC, for distribution per UC-90C (278)

Manager, Chicago Operations and Regional Office, DOE

Chief, Office of Patent Counsel, DOE-CORO

President, Argonne Universities Association

Energy and Environmental Systems Division Review Committee:

E.E. Angino, U. Kansas

R.E. Gordon, U. Notre Dame

W.W. Hogan, Harvard U.

L.H. Roddis, Jr., Charleston, S.C.

G.A. Rohlich, U. Texas at Austin

R.A. Schmidt, Booz, Allen \& Hamilton

Jack Abrahams, Fossil Energy' Program, USDOE (3).

Katherine Alben, N.Y. Dept. of Health, Albany, NY

Louis Anastasia, Inst. Gas Technology, Chicago, IL

Thomas Atkins, Mittelhauser Corp., Downers Grove, IL (3)

Robert A. Baker, USGS, Water Resources Div., NSTL Station, MS

M.L. Bender, Dept. of Chemistry, Northwestern Univ., Evanston, IL

Rudolf Bieri, Virginia Institute of Marine Science, Gloucester Pt., VA Richard Biljetina, Environmental Eng., Inst. Gas Technology, Chicago, IL Bill Brewer, Dept. of Bio. Sciences, Wright State Univ., Dayton, OH Mayo Carrington, Fossil Energy Program, USDOE (3)

John C. Craun, Environmental Res. \& Tech., Pittsburgh, PA

Stephen A. Dudley, Normandeau Assoc., Bedford, NH

Paul Duhamel, Biomedical \& Environmental Res., USDOE

Jackson Ellingtion, EPA, Athens, GA

Dick Engen, ITT Rayonier, Shelton, WA

Davis Ford, Engineering-Science, Austin, TX

C.S. Giam, Chemistry Dept., Texas A\&M, College Station, TX

J.H. Gibbons, Office of Technology Assessment, U.S. Congress

Stephen E. Herbes, ORNL, Oak Ridge, TN

Michael Hoffmann, Univ. of Minnesota, Minneapolis, MN 
Ami Horowitz, Dept. of Soil Sci., Michigan State Univ., E. Lansing, MI Philip H. Howard, Syracuse Research Corp., Syracuse, NY

Doug Johnson, Univ. of Tenn., Knoxville, TN

G.J. Karabatsos, Dept. of Chemistry, Michigan State Univ., E. Lansing, MI

D.E. Kash, USGS, Reston, VA

Library, Virginia Inst. of Marine Science, Gloucester Pt., VA

Richard G. Luthy, Carnegie-Mellon Univ,, Pittsburgh, PA (20)

M.J. Massey, Environmental Res. \& Tech., Pittsburgh, PA (2)

H.M. Mehendale, Dept. of Pharm. \& Toxi., Univ. of Miss., Jackson, MS

Calvin Menzie, FWS/FER, USDI, Washington, D.C:

Roger A. Minear, Dept. of Civil Eng., Univ. of Tenn., Knoxville, TN

Leslie Nelken, Arthur D. Little, Cambridge, MA

Doris F. Paris, EPA-ERL EPB, Athens, GA

Leland E. Paulson, USDOE, GFETC, Grand Forks; ND (3)

Harriette L. Phelps, Univ. of C.C., Washington, D.C.

D. Rapisarda, DuPont-Biochemicals, Wilmington, DE

David Schultz, USGS, NSTL Station, MS.

Jack P. Schwartz, Inst. of Marine Sciences, Univ. of Alaska, Fairbanks, AK

D.G. Shaw, Inst. of Marine Sciences, Univ. of Alaska, Fairbanks, AK

M.S. Simmons, Dept. of Env. \& Ind. Health, Univ. of Mich.; Ann Arbor, MI

Philip Singer, Univ. of North Carolina, Chapel Hill, NC

Vernon Snoeyink, Dept. of Civil Eng., Univ. of I11., Urbana, IL

George Stapelton, Dept. of Biomed \& Environmental Res., USDOE, Washington, D.C.

R.R. Stephenson, Tunstall Lab., Sittingbourne Kent, England

G. Stout, Water Res Ctr., Univ. of Ill., Urbana, IL .

Daniel P. Thoman, The Mitre Corp., McLean, VA

Armand Thomas, A.F. Meyer Assoc., McLean, VA

W. Tsang, Nat1. Bureau of Standards, Washington, D.C.

Kurt White, Pittsburgh Energy Technology Center, USDOE, Pittsburgh, PA

Fred Witmer, Div. of Envir. Control Tech., USDOE, Washington, D.C.

Richard C. Young, Aquatic Tox. Lab-U.S. TVA, EDB, Muscle Shoals, AL 